\title{
Skeletal muscle ischemia and reperfusion increase lipid peroxidation in rats ${ }^{1}$
}

\author{
Isquemia e reperfusão do músculo esquelético aumenta a peroxidação lipídica em \\ ratos
}

\author{
Carlos Eli Piccinato², Armando De Domenico $\mathrm{Jr}^{3}$, Alceu Afonso Jordão $\mathrm{Jr}^{4}$, Helio Vannucchi ${ }^{5}$ \\ 1.Department of Surgery and Anatomy, Faculty of Medicine of Ribeirão Preto, University of São Paulo. Ribeirão Preto/ \\ SP, Brazil. \\ 2.Professor, Doctor. Department of Surgery and Anatomy, Faculty of Medicine of Ribeirão Preto, University of São \\ Paulo. \\ 3.Post-Graduation Student. Department of Surgery and Anatomy, Faculty of Medicine of Ribeirão Preto, University of \\ São Paulo. \\ 4.Professor, Doctor. Department of Internal Medicine, Faculty of Medicine of Ribeirão Preto, University of São Paulo. \\ 5.Professor, Doctor. Chief of Nutrition Clinical Division. Department of Internal Medicine, Faculty of Medicine of \\ Ribeirão Preto, University of São Paulo.
}

\begin{abstract}
PURPOSE: To determine the effects of 30 minutes of ischemia followed by 30 minutes of reperfusion in skeletal muscle of rats receiving three different diets (supplemented, normal and vitamin E deficient) on lipoperoxidation (LP).

METHODS: LP measured by TBARS levels, and plasma and hepatic concentrations of vitamin E measured by HPLC.

RESULTS: The deficient group presented higher lipoperoxidation levels in muscle compared to the control and supplemented groups.

CONCLUSION: Supplementation with vitamin E decrease the free radicals production in ischemia/ reperfusion in skeletal muscle of rats.
\end{abstract}

KEY WORDS: Ischemia. Skeletal muscle. Vitamin E. Free radicals. Rats.

\section{RESUMO}

OBJETIVO: Existem evidências que nos processos de isquemia e reperfusão do músculo esquelético pode ocorrer uma maior formação de radicais livres e que os efeitos deletérios destes radicais podem ser inibidos pela presença de substâncias antioxidantes, como a vitamina E.

MÉTODOS: O presente trabalho demonstra os efeitos de 30 minutos de isquemia seguido de 30 minutos de reperfusão em músculo esquelético de ratos Wistar recebendo 3 diferentes dietas: suplementada 20 vezes (GS), controle (GC) e deficiente em vitamina E por 30 dias (GD), sobre a taxa de peroxidação lipídica e níveis plasmáticos e musculares de vitamina E.

RESULTADOS: As médias de pesos e de ingestão dietética dos grupos experimentais a cada semana mostrou que não houve diferença estatística significativa entre os 3 grupos que receberam dietas com teores diferentes de vitamina E. Quanto aos valores de vitamina E existiu diferença entre os 3 grupos no músculo, sendo respectivamente o deficiente menor que o controle e menor que o suplementado (GD $2.15 \pm 0.44$, GC $6.37 \pm 1.66$ e GS $18.43 \pm 1.80$, p <0,05). Os valores musculares das peroxidação lipídica foram altamente influenciados pela dieta, tendo um aumento significativo no grupo deficiente em vitamina E. Estes resultados fortalecem a hipótese de que a isquemia e reperfusão são processos geradores de radicais livres e que uma dieta rica em vitamina E pode atuar como fator protetor contra a peroxidação lipídica.

CONCLUSÃO: Os músculos esqueléticos de ratos isquêmicos e reperfundidos tratados com dieta suplementada com vitamina E por quatro semanas apresentam taxa menor de peroxidação lipídica quando comparados com aqueles do grupo de ratos tratados com dieta controle e que uma dieta deficiente em vitamina $\mathrm{E}$ favorece o aumento dos radicais livres. 
DESCRITORES: Isquemia. Músculo esquelético. Vitamina E. Radicais livres. Ratos.

\section{Introduction}

There is evidence that greater formation of free radicals can occur in processes of skeletal muscle ischemia and reperfusion, with consequent damage to amino acids, carbohydrates and especially unsaturated lipids present in the cell membrane ${ }^{1}$. Among the other consequences of this process is the presence of mediators of inflammation, leukocyte infiltration, phospholipid peroxidation, changes in nitric oxide metabolism, and reduction of ATP production ${ }^{2}$.

These deleterious effects can be attenuated by interference with, or modulation of, the physiopathological processes that occur during ischemia and reperfusion ${ }^{2}$. In addition, the deleterious effects of free radicals can be inhibited by the presence of antioxidant substances such as vitamin $\mathrm{E}$ which can inhibit the occurrence of lipid peroxidation $^{3,4}$.

Formigli et al. ${ }^{5}$ postulated that treatment with vitamin $\mathrm{E}$ can be considered as a tool for protection against the damage of ischemia-reperfusion in human skeletal muscle.

Thus, the objective of the present study was to determine the effects of 30 minutes of ischemia followed by 30 minutes of reperfusion in skeletal muscle of rats receiving 3 different diets (supplemented, normal and vitamin E deficient) on lipoperoxidation rate measured by TBARS levels, and plasma and hepatic concentrations of vitamin $\mathrm{E}$.

\section{Methods}

The study was conducted on 30 newly weaned male Wistar rats weighing on average $60 \mathrm{~g}$, from the Central Animal Colony of FMRP-USP. The animals were divided into three groups:

Control Group (CG, $n=10$ ): rats receiving a normal vitamin $\mathrm{E}$ diet for one month and submitted to 30 minutes of skeletal muscle ischemia followed by 30 minutes of reperfusion Supplemented Group (SG, $n=10$ ): rats receiving a diet supplemented with 30 -fold the recommended amount of vitamin
E for one month and then and submitted to 30 minutes of skeletal muscle ischemia followed by 30 minutes of reperfusion

Deficient Group (DG, $n=10$ ): rats receiving a deficient, vitamin E-free diet for one month and then submitted to 30 minutes of skeletal muscle ischemia followed by 30 minutes of reperfusion.

The diets offered to the animals were prepared according to 1975 AOAC recommendations ${ }^{6}$. Both the diets and water were offered ad libitum. The animals were housed in individual cages on an artificial 12 hour light- 12 hour dark schedule, at a mean temperature of $22^{\circ} \mathrm{C}$.

Ingestion was controlled by regular weighing of the feeders twice a week and the animals were weighed every 4 days. At the end of 30 days, the animals were operated one by one in the CG, SG and DG sequence under general ethyl ether anesthesia. After median laparotomy, the abdominal aorta was exposed by blunt dissection and occluded distally to the emergence of the renal arteries with an atraumatic vascular clamp for a period of 30 minutes according to the partial acute ischemia model of Perry and Fantini ${ }^{7}$. Acute ischemia was confirmed on the basis of hind paw cyanosis and coldness. After this period of ischemia, the vascular clamp was removed and reperfusion was allowed to occur for 30 minutes. Reperfusion to the hind limbs was characterized by warming and by the return of color in the extremities.

The animals were anesthetized with ether and sacrificed by exsanguination after removal of $10 \mathrm{ml}$ blood by cardiac puncture (right ventricle) for the determination of plasma vitamin E levels. Muscle samples (2 to $3 \mathrm{~g}$ of gastrocnemius and digitorum flexor muscles) were then collected, weighed, and placed in Eppendorf tubes which were immediately stored in liquid nitrogen ($196^{\circ} \mathrm{C}$ ) for later determination of TBARS and atocopherol. 


\section{Laboratory methods}

TBARS were measured in muscle by the method of Buege \& Aust $^{8}$, and TBARS values are expressed on the basis of protein amount in muscle.

Analysis of vitamin E (a-tocopherol) was carried out on plasma and muscle samples by HPLC (Shimadzu ${ }^{\circledR}$ ) using a C-18 type column (Shimpack CLC-ODS 4.6 x $25 \mathrm{~cm}$ ), a $4 \mathrm{~mm} \times 1$ cm precolumn and a flow rate of $2.0 \mathrm{~mL} / \mathrm{min}$, with readings taken with a UV/Vis detector at $292 \mathrm{~nm}^{9}$.

Data are reported as means \pm standard deviation. Groups were compared by analysis of variance (ANOVA) and by the Tukey test, with the level of significance set at $\mathrm{p}<0.05$.

\section{Results}

Analysis of variance of mean weekly weight data for the experimental groups showed no significant difference $(\mathrm{p}<0.05)$ between the 3 groups receiving diets with different vitamin $\mathrm{E}$ contents (Table 1). Diet ingestion also did not differ significantly between groups (data not shown).

Analysis of variance showed that the deficient group presented higher TBARS levels in muscle compared to the control and supplemented groups. With respect to vitamin $\mathrm{E}$ values, the 3 groups differed both in muscle and plasma, with the following sequence: SG > CG > DG (Table 2).

TABLE 1 - Weight evolution (g) in the different groups of rats submitted to ischemia and reperfusion of skeletal muscle.

\begin{tabular}{lccc}
\hline Groups & Control & Supplemented & Deficient \\
\hline Initial Weight (g) & $50.27 \pm 6.72 \mathbf{a}$ & $51.38 \pm 5.89 \mathbf{a}$ & $53.14 \pm 5.77 \mathbf{a}$ \\
Final weight (g) & $244.76 \pm 17.01 \mathbf{a}$ & $243.39 \pm 11.84 \mathbf{a}$ & $250.31 \pm 10.05 \mathbf{a}$ \\
\hline
\end{tabular}

Different letters on the same line indicate a significant difference for $\mathrm{p}<0.05$.

TABLE 2 - Lipid peroxidation and vitamin E levels in rats submitted to ischemia and reperfusion of skeletal muscle.

\begin{tabular}{|c|c|c|c|}
\hline Groups & Deficient & Control & Supplemented \\
\hline Plasma VE ( $\mu \mathrm{mol} / \mathrm{l})$ & $11.13 \pm 4.50 \mathbf{a}$ & $26.48 \pm 3.95 \mathbf{b}$ & $45.58 \pm 11.90 \mathrm{c}$ \\
\hline Muscle Vo ( $\mu \mathrm{g} / \mathrm{g})$ & $2.15 \pm 0.44 \mathbf{a}$ & $6.37 \pm 1.66 \mathbf{b}$ & $18.43 \pm 1.80 \mathrm{c}$ \\
\hline TBARS (nM/mg pt) & $0.92 \pm 0.37 \mathbf{a}$ & $0.73 \pm 0.35 \mathbf{a b}$ & $0.44 \pm 0.23 \mathbf{b c}$ \\
\hline
\end{tabular}

Different letters on the same line indicate a significant difference for $\mathrm{p}<0.05$.

\section{Discussion}

The animals in the different groups ingested similar amounts of ration and therefore did not differ significantly in weight at the end of the 4 weeks of the experiment. Muscle TBARS values were highly influenced by diet, showing a statistically significant increase in the vitamin Edeficient group and a reduction in the supplemented group compared to control.

Increased TBARS production is strong evidence that lipid peroxidation is one of the mechanisms of tissue damage influenced by vitamin E levels in the diet. In a previous study, Vannucchi et al. ${ }^{3}$ postulated that vitamin $\mathrm{E}$ deficiency may induce lipid peroxidation in the rat liver and that the maintenance of adequate or high vitamin E levels in the diet may act as a protective factor against the generation of free radicals.

Grisotto et al. ${ }^{10}$ demonstrated that, after a 3 hour ischemia, there are signs of damage to the phospholipid membrane of rat skeletal muscle, but few changes in the oxidative status of the cells. However, after 45 minutes of reperfusion, significant changes in the oxidative picture occurred, with an increase in oxidized glutathione and malondialdehyde.

\section{Conclusions}

These results support the hypothesis that ischemia and reperfusion are free radicalgenerating processes and that a vitamin E-rich diet can act as a protective factor against lipid peroxidation. We conclude that skeletal muscle of 
ischemic and reperfused rats treated with a vitamin E-supplemented diet for 4 weeks present a lower lipid peroxidation rate compared to rats treated with a control diet and with a vitamin E-deficient diet and that a vitamin E-deficient diet favors an increase in free radicals.

\section{References}

1. Halliwell B. Antioxidants and human disease: a general introduction. Nutr Rev 1997; 55:S44-52.

2. Rubin BB, Romaschin A, Walker PM, Gute DC, Korthuis RJ. Mechanisms of postischemic injury in skeletal muscle: intervention strategies. J Appl Physiol 1996; 80: 369-87.

3. Vannucchi H, Jordão Junior AA, Iglesias AC, Morandi MV, Chiarello PG. Effect of different dietary levels of vitamin $\mathrm{E}$ on lipid peroxidation in rats. Arch Latinoam Nutr 1997; 47: 34-7.

4. Vannucchi H, Moreira EAM, Cunha DF, JunqueiraFranco MVM, Bernardes MM, Jordão Jr AA. Papel dos nutrientes na peroxidação lipídica e no sistema de defesa antioxidante. Medicina (Ribeirão Preto) 1998; 31: 31-44.

5. Formigli L, Ibba Manneschi L, Tani A, Gandini E, Adembri C, Pratesi C, Novelli GP, Zecchi Orlandini S. Vitamin E prevents neutrophil accumulation and attenuates tissue damage in ischemic-reperfused human skeletal muscle. Histol Histopathol 1997; 12: 663-9.

6. Association of Official Analytical Chemists (A.O.A.C.). Official methods of analysis. 12ed. Washington DC; 1975.

7. Perry MO, Fantine MD. Ischemia: profile of an enemy. Reperfusion injury of skeletal muscle. J Vasc Surg 1987;6: 231-4.

8. Buege JA, Aust SD. Microsomal lipid peroxidation. Meth Enzymol 1978; 52:302-10.

9. Arnauld J, Fortis I, Blachier S, Kia D, Favier A. Simultaneous determination of retinol, a-tocopherol and b-carotene in serum by isocratic high performance liquid chromatography. J Chromatogr 1991; 572:103-6.

10. Grisotto PC, Santos AC, Coutinho-Neto J, Cherri J, Piccinato CE. Indicators of oxidative injury and alterations of the cell membrane in the skeletal muscle of rats submitted to ischemia and reperfusion. J Surg Res 2000;92:1-6.

Correspondence:

Carlos Eli Piccinato

Faculty of Medicine of Ribeirão Preto

Department of Surgery and Anatomy, University of São Paulo

Av. Bandeirantes, 3900

14049-900 Ribeirão Preto - SP, Brazil

cepiccin@fmrp.usp.br

Received: May 15, 2004

Review: June 25, 2004

Accepted: July 19, 2004

Conflict of interest: none

Financial source: none

How to cite this article:

Piccinato CE, De Domenico Jr A, Jordão Jr AA, Vannucchi H. Skeletal muscle ischemia and reperfusion in rats increase lipid peroxidation in rats. Acta Cir Bras [serial online] 2004 Sept-Oct;19(5). Available from URL: http://www.scielo.br/acb [also in CD-ROM]. 